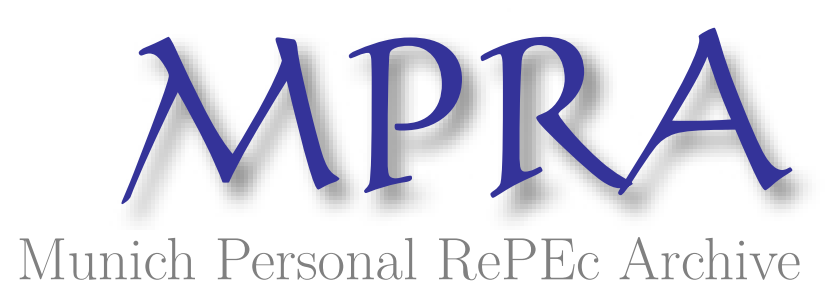

\title{
Root Causes of The Housing Bubble
}

Kaizoji, Taisei

International Christian University

10 August 2009

Online at https://mpra.ub.uni-muenchen.de/16808/

MPRA Paper No. 16808, posted 16 Aug 2009 08:19 UTC 


\title{
Root Causes of The Housing Bubble
}

\author{
Taisei Kaizoji
}

\begin{abstract}
In this chapter we investigate root causes of the recent U.S. housing bubble which has been caused a serious downturn in U.S. economic growth since autumn of 2008. We propose a simple model of housing markets in order to indicate the possible determinants of recent housing prices. Utilizing the model, we verify a number of hypotheses which have been proposed in the recent literature on the housing bubbles. We suggest that the main causes of the housing bubble from 2000 to 2006 are (i) non-elastic housing supply in the metropolitan areas, and (ii) declines in the mortgage loan rate and the housing premium by the massive mortgage credit expansion. We also suggest that these factors were strongly influenced by policies that governments and the Federal reserve Board performed.
\end{abstract}

\section{Introduction}

The principal cause of the current financial and economic crises is the housing bubble. The housing bubble in US was the biggest financial bubble in the recent history in US. The unprecedented U.S. housing bubble began to inflate in the first quarter of 1998 and continued till the second quarter of 2006. Then the housing prices began falling, and as of July 2009 the housing price still has been falling. The housing market meltdown was triggered by a dramatic rise in mortgage delinquencies and foreclosures for subprime residential mortgage loans.

Figure 1 shows the nominal housing price index and the real housing price index which is adjusted for inflation from 1890 to 2009. From 1998 to a peak in 2006, the nominal housing price index increased by 130 percent and the inflation adjusted housing prices index increased by 80 percent. The growth rate of the nominal housing price index had averaged 2.9 percent between 1890 and 1997, and averaged 9.3 percent between 1998 and 2007. The real housing price index increased by an aver-

Taisei Kaizoji

International Christian University, Tokyo 181-8585, Japan, e-mail: kaizoji@icu.ac.jp 
age of 6.8 percent a year from 1997 to 2006 while the index increased by an average of 0.086 percent a year from 1890 to 1997 . The nominal housing price index decline by 4.2 percent from the first quarter of 2007 to the first quarter of 2009 while the real housing price declines by 4.9 percent per a quarter for the same period.

The housing bubble had an immeasurable negative impact on the US economy because they caused misallocation of resources, and furthermore, the housing market crash destroyed a large amount of wealth. What is most important things that we learned in order to prevent the disaster? this chapter investigate the reasons why the housing bubble was caused through verifying hypotheses which have been proposed in the recent literature on the housing bubbles. To give a theoretical background of the determinants of housing prices, we propose a simple model of housing markets which is based on the classical economics.

\section{A simple model of housing markets}

In this session we propose a simple of housing markets and derive an theoretical housing price in the housing markets. We formalize the price-to-rent ratio in the framework of the household's utility maximization. We assume that the household makes a optimal decision regarding consumption of goods and housing services for the present. The utility of the household who owns a house is given by the following form:

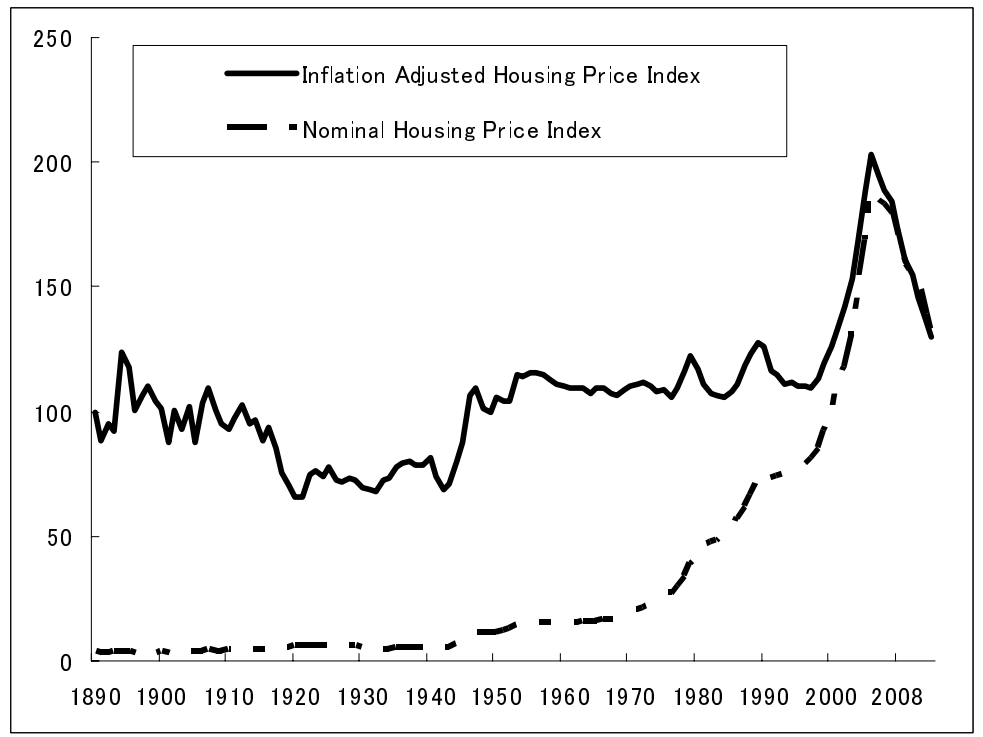

Fig. 1 The US housing price index: Data for Figure 1 was provided by Robert J. Shiller, Irrational Exuberance, 2nd. Edition, Princeton University Press,2005 as updated by author. 


$$
U^{H}\left(c^{H}, s^{H}\right)=\alpha \log c^{H}+\beta \log s^{H}
$$

where $\alpha$ and $\beta$ are the parameters which express the household of preference. The household's budget constraint is:

$$
c^{H}+\tilde{p} s^{H}=y^{H}
$$

$c^{H}$ denotes a homeowner's consumption, $s^{H}$ his demand for housing, and $y^{H}$ his real disposable income. $\tilde{p}$ denotes the user cost of home ownership, known in the housing literature as the imputed rent (see Hendershott and Slemrod, 1983, Portaba (1984, 1992)). It is defined as follows:

$$
\tilde{p}=p(i+\tau+f-\pi)
$$

where

1. $i$ is the after-tax nominal interest rate,

2. $\tau$ is the property tax rate on owner-occupied houses,

3. $f$ is the recurring holding costs,

4. $\pi$ is the expected capital gain (or loss),

5. $p$ is the house price.

$i$ is the cost of foregone interest that the homeowner could have earned on an alternative investment. $f$ consists of depreciation, maintenance and the risk premium on residential property.

Hence, the household's utility maximization problem is formulated as:

$$
\begin{gathered}
\max U\left(c^{H}, s^{H}\right) \\
\text { s.t. } c^{H}+\tilde{p} s^{H}=y^{H} .
\end{gathered}
$$

The problem is solved by forming the Lagrangean

$$
L\left(c^{H}, s^{H}, \lambda\right)=U\left(c^{H}, s^{H}\right)+\lambda\left[y^{H}-c^{H}-\tilde{p} s^{H}\right]
$$

The first-order conditions to find the critical points of the Lagrangean function are:

$$
\begin{gathered}
\frac{\partial L}{\partial c^{H}}=\frac{\alpha}{c^{H}}-\lambda=0, \\
\frac{\partial L}{\partial s^{H}}=\frac{\beta}{s^{H}}-\lambda=0, \\
\frac{\partial L}{\partial \lambda}=y^{H}-c^{H}-\tilde{p} s^{H}=0 .
\end{gathered}
$$

Consumption $\mathrm{c}$ and the demand for housing services $\mathrm{s}$ are obtained as:

$$
c^{H}=\alpha y^{H}, \quad s^{H}=\beta \frac{y^{H}}{\tilde{p}} .
$$


Secondly, let us consider the utility maximization problem of the household who rents a house. We assume that the household, who rents a house, has the same utility function as that of the household who owns a house.

$$
U^{R}\left(c^{H}, s^{H}\right)=\alpha \log c^{R}+\beta \log s^{R} .
$$

The renter's budget constraint is:

$$
c^{R}+w s^{R}=y^{R} .
$$

Solving the first-order conditions, consumption $c^{R}$ and the demand for housing services $s^{R}$ by the household who rents a house are obtained as:

$$
c^{R}=\alpha y^{R}, \quad s^{R}=\beta \frac{y^{R}}{w} .
$$

$c^{R}$ denotes a renter's consumption, $s^{R}$ his demand for housing, and $y^{R}$ his real disposable income. Aggregate demand for purchasing houses is:

$$
\sum_{i=1}^{n_{1}} s_{i}^{H}=\frac{\beta y^{H}}{\tilde{p}} n_{1} .
$$

where $n_{1}$ denotes the number of households who own a house. The aggregate demand for leasing houses is:

$$
\sum_{j=1}^{n_{2}} s_{j}^{R}=\frac{\beta y^{R}}{w} n_{2} .
$$

where $n_{2}$ denotes the number of households who rent a house.

We assume that the supply of housing is constant: $N_{1}$ and $N_{2}$. In equilibrium, the demand has to be equal to supply,

$$
\frac{\beta y^{H}}{\tilde{p}} n_{1}=N_{1}, \quad \text { and } \quad \frac{\beta y^{R}}{w} n_{2}=N_{2} .
$$

Arranging (11), the price-to-rent ratio is written as

$$
\frac{p}{w}=\frac{n_{1}}{n_{2}} \frac{N_{2}}{N_{1}} \frac{y^{H}}{y^{R}} \frac{1}{(i+\tau+f-\pi)} .
$$

We introduce the new variable,

$$
s=\frac{\left(n_{1}-n_{2}\right)}{2 N}=\frac{1}{2 N} \sum_{j=1}^{2 N} s_{j}, \quad(-1 \leq s \leq 1) .
$$

where $n_{1}+n_{2} \equiv 2 N$. The variable $s$, indicates the homeownership rate. Then we can rewrite the price-to-rent ratio as follows:

$$
\frac{p}{w}=\frac{(1+s)}{(1-s)} \frac{N_{2}}{N_{1}} \frac{y^{H}}{y^{R}} \frac{1}{(i+\tau+f-\pi)} .
$$


As many literatures show, when the following conditions are hold: $n_{1}=n_{2}$, $N_{1}=N_{2}$ and $y^{H}=y^{R}$, the expected annual cost of owning a house equals that of renting at an equilibrium in the housing market, that is, $\tilde{p}=w$ (see Poterba (1984), Himmelberg, Mayer, and Sinai $(2005)^{1}$ ).

\subsection{The price-to-rent ratio}

The price-to-rent ratio is a measure which is commonly used to get an indication of over or undervaluation in terms of the cost of owning versus renting a house. If this ratio rises above its long-term average, then it could be an indication that prices are overvalued.

Figure 2 shows the ratio of price to rent from the first quarter of 1960 to the first quarter of 2009. The figure shows that the price-to-rent ratio ranged between

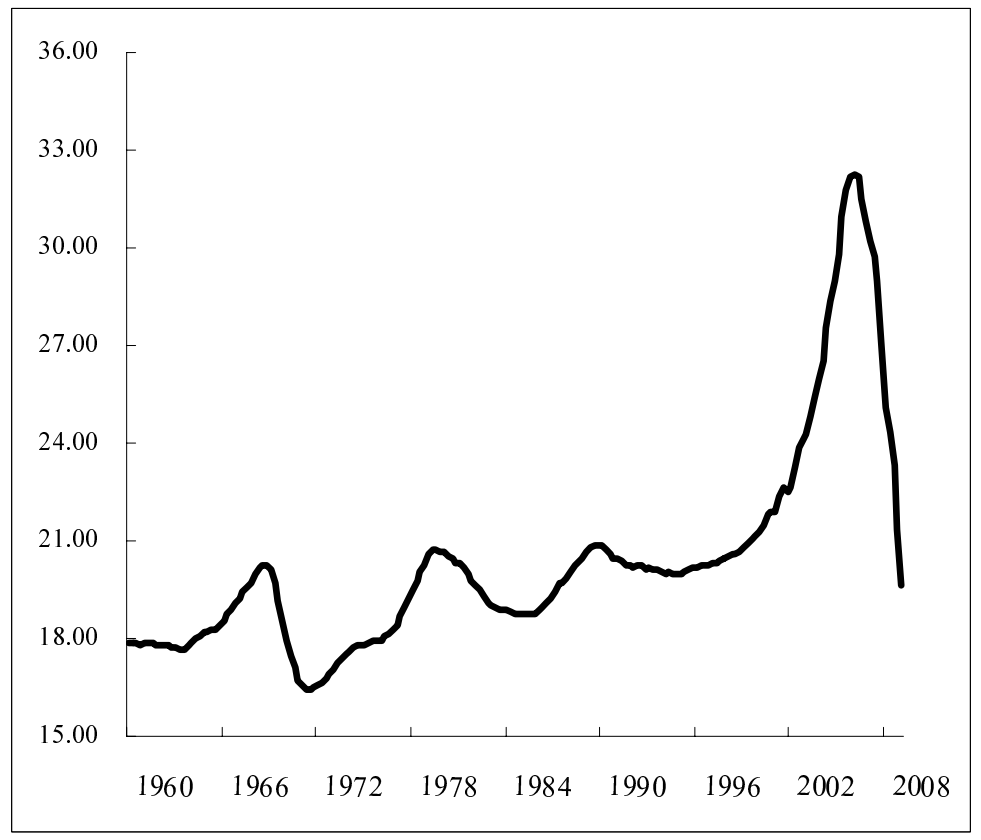

Fig. 2 The Price-to-rent ratio for the aggregate stock of owner-occupied housing: Data for Figure 2 was provided by Davis,. Lehnert, and Martin (2008).

\footnotetext{
${ }^{1}$ They implicitly assume low-cost arbitrage between owning and renting and the supply of housing were perfectly elastic. In reality, mortgage origination fees, broker commissions and moving costs make it expensive to switch back and forth between owning and renting. As we show below, the housing supply is often regulated by the local governments.
} 
16.5 and 20 times between 1960 and 1995, but the rent-price ratio rapidly increased after 1995, and reached an historic high of 32 times by year-end 2006. Since the first quarter of 2007, the price to rent ratio decreased from its historical high, and the latest data suggest that the ratio has continued to decrease. (Davis, Lehnert, and Martin (2007)).

A related finding is that price-to-rent ratio differs across cities and the differences are persistent over time: cities with high price-to-rent ratios tend to remain high, and cities with low price-to-rent ratio remain low. (See Himmelberg, Mayer, and Sinai (2005)). The price-to-rent ratios in 2006 are substantially above their longterm averages. In the metropolitan areas with the largest house price increases, these ratios exceed their long-term averages significantly. The unprecedented and steep increase in the price-to-rent ratio lead us to conclude that the housing markets in the metropolitan areas experienced a sizeable bubble over the 1995-2006 period. Davis, et.al.(2007) forecasts that assuming nominal rents were to increase by 4 percent per year, about the average since 2001, a decline in nominal house prices of about 3 percent per year would bring the rent-price ratio up to its historical average, 5 percent, by mid-2012.

\section{Determinants of Housing Prices}

Although rapid derivation of the price-to-rent ratio from the long-term average is necessarily evidence of overvaluation of housing price, the ratio of prices to rent by itself is not a sufficient metric to indicate possible causes of the housing bubble. To address this issue, it is necessary to relate the price-to-rent ratio to their underlying determinants in the right hand side of the equation (14). We focus attentions on is the following: (i) income, $y^{H}$, (ii) housing supply, $N_{1}$, (iii) the user cost of home ownership, $\tilde{p}$, and (iv) homeownership rate, $s$.

\subsection{Price-to-income ratio}

Another measure that is commonly used to assess whether housing prices are unsustainably high is the price-to-income ratio, which provides a measure of local housing costs relative to the local ability to pay (see, for examples, Girouard, Kennedy, van den Noord, and Andre (2006), and Himmelberg, Mayer and Sinai (2005)). Himmelberg, Mayer and Sinai (2005) investigates the price-to-income ratio computed as the OFHEO price index divided by an index of median per-capita income based on data from the U.S. Bureau of Economic Analysis. They show that at the national level the growth in real house prices was outpaced by the high growth in incomes (See also McCarthy and Peach, 2004). However, at the metro area level, price-toincome ratios have generally increased the most in cities where house price growth has been highest such as Boston, New York, San Francisco and San Diego. Price- 
to-income in 2004 is above its peak value in many of these cities, and as much as 40-50 percent above its 25-year average. But in Houston, Dallas and other southern cities, price-to-income is well below its 25 -year average. Gyourko, Mayer, and Sinai (2004) refers to cities with high long-run rates of house price growth such as San Francisco, Boston, New York, and Los Angeles as superstar cities, and show that differences in house price and income growth rates across metropolitan areas have led to an ever-widening gap in housing values and incomes between the typical and highest-priced locations. They argue that the new home buyers in superstar cities are high-income households who have moved from other parts of the country, so that those cities can experience above-average house price growth over a very long horizon under tight supply constraints.

\subsection{Elasticity of housing supply}

In principle, if the housing market is perfect competitive, and the supply of housing is perfectly elastic, house prices would be determined solely by construction costs (Muth 1960). In practice, the housing prices have derived from the housing cost in many metropolitan area over the long-run period. Glaeser, Gyourko, and Saks (2005) investigates the ratio of the average house price to the estimated physical construction cost for 102 metropolitan areas in each Census year from 19502000. They found that house prices grew relative to construction costs in most of the metropolitan statistical areas. The rise in the gap between price and construction cost throughout parts of the Northeast and the West coast over the past three decades. Therefore, changes in construction costs explain neither the overall rise in real house prices nor cross-sectional differences in appreciation rates across markets. Several studies on the US regional housing markets have found that the low supply elasticity of housing units is an important factor behind the recent larger price increases in some urban markets, and have argued that housing supply regulation is an important determinant of house prices (Glaeser and Gyourko (2003), Glaeser, Gyourko, and Saks (2005), and Gyourko, Mayer, and Sinai (2004)). They argue that differences in appreciation rates of housing across metropolitan areas reflect tight housing supply regulation combined with an increasing number of households who want to live in the area. They also point out that US homebuilders have faced increasing difficulty in obtaining regulatory approval for the construction of new homes in some states, (for notable examples, California, Massachusetts, New Hampshire, and New Jersey) and in Washington, D.C. An additional factor has been the increased ability of established residents to block new projects. The supply constraint on new construction have push up prices relative to construction cost, and this is considered to be able to explain partially house price overheating in housing markets in the metropolitan area. 


\subsection{The user cost of home ownership}

Campbell et. al. (2009) uses Campbell and Shiller's (1989) dynamic Gordon growth model to decompose the log rent-price ratio, $v$, into three components: the expected present value of real interest rates (the real 10-year Treasury), $\tilde{r}_{t}$, and the expected present value of the housing premium, $\sigma_{t}$, and the expected present value of real rent growth, $\tilde{w}_{t}$ :

$$
v_{t}=\kappa+\tilde{r}_{t}+\sigma_{t}-\tilde{w}_{t} .
$$

which is an alternative to the rent-to-price ratio proposed by Portaba (1984). Campbell et. al. (2009) shows that both of real interest rates and housing premia have fallen from 1997 to 2005 in almost all the metropolitan areas, and almost all of the decline in the rent-to-price ratio (inversely, increase in the price-to-rent ratio) is attributable to a steep decline in the risk premium paid to housing over and above a 10-year Treasury bond, and a decline in the expected present values of real interest rate. Especially they indicate that the housing premium plays a relatively more important role, and can explain about 65 percent of the recent run-up of house prices relative to rents since 1997.

\subsection{Policies}

Why did both of the real interest rate and the risk premium paid to housing declined sharply over the 1997-2005 period?

First, the Federal Reserve Board sharply lowered its sort-term interest rates in response to the recession caused by bursting internet bubbles in 2000. The Fed Funds rate dropped from 6.5 percent at the end of 2000 to 1 percent in mid-2003. The Federal Reserve's monetary policy in this period was overly accommodative compared to the optimal policy suggested by the so called Tayler rule (Taylor $(1993,2007)$ ). As a result, banks, other financial institutions eagerly expanded credit through loans and investments in debt and derivative securities. As a result, monetary policy helped hold mortgage rates at a low level. Taylor (2007) argue that this significant deviation may have been a cause of the boom and bust in US housing market.

Second, federal policymakers have promoted home-ownership as the fulfillment of the 、 merican dream." Especially the Clinton administration encouraged homebuying among financially marginal and minority households. To purse this aim, the administration performed the following policies: (i) enacting preferential income tax policies to reduce the cost of home ownership relative to renting, (ii) pressing depository institutions and mortgage banks to lower their credit standards and reduce down payment requirements, and (iii) promoting exotic alternatives to traditional fixed-rate fully amortizing residential mortgage loans, such as interest-only residential mortgage loans and negatively amortizing residential mortgage loans. (For a detailed documentation, see Saxton (2008)). These policies were intended to help financially marginal and minority households that could not qualify for traditional 
mortgage loans under normal credit standards to buy homes. The Bush administration left these Clinton administration policies in place.

\subsection{Home ownership rate}

The federal government's policies encouraged many financially marginal and minority households to buy housing during the bubble. Thereby, the home ownership rate increased to a peak of 69.0 percent in 2004 while the rate had averaged 64.3 percent of all households from 1982 to 1997 . These policies designed to help financially marginal and minority households generated many households who buy homes through unaffordable subprime residential mortgage loans. However, many of these new home owners had poor credit histories, and were unprepared or unable to discharge their mortgage obligations.

\section{Concluding Remarks}

In this chapter we study the reasons why the housing price was inflated excessively in US. To this aim, we propose a simple model of housing market. The main causes of the housing bubble are summarized as:

(i) non-elastic housing supply in the metropolitan areas,

(ii) declines in the interest rate and the housing premium.

First, inflation of the housing prices in highest-price areas, especially New York City and California does not reflect physical costs of construction, but zoning strictness and other restrictions on building by government regulations. These findings suggests that policy makers of local governments possibly prevented the housing bubble through appropriate zoning reform in the metropolitan area.

Second, Federal policymakers adopted a number of policies to promote home ownership and help financially marginal and minority households to buy homes with unaffordable subprime residential mortgage loans. After all, these policies made households vulnerable to foreclosure after the housing bubble burst, and caused a serious downturn in U.S. economic growth.

Finally, the Federal Reserve's monetary policy which was overly accommodative from the second quarter of 2002 through the third quarter of 2006 lowered the cost of funds for financial institutions, and encouraged them to expand credit aggressively by extending loans. The policies created a massive credit expansion and stimulated the demand for housing among households. As a result, U.S. housing prices soared. In conclusion, Federal policymakers could also have adopted a number of policies to preventing housing bubble. 


\section{References}

1. Campbell, J. and Shiller, R.: Stock Prices, Earnings and Expected Dividends, Journal of Finance, 43, 661-676 (1998).

2. Campbell, S., Davis, M., Gallin, J. and R. Martin: gWhat Moves Housing Markets: A Variance Decomposition of the Rent-Price Ratio, forthcoming into Journal of Urban Economics (2009).

3. Davis, M. A., Lehnert, A., Martin, R. F.: The Rent-Price Ratio: for the Aggregate Stock of Owner-Occupied Housing, Review of Income and Wealth, (2008), vol. 54 (2), p. 279-284.

4. Girouard, N., Kennedy, M., van den Noord, P., Christophe Andre, C.: Recent House Price Developments: The Role of Fundamentals, OECD Economics Department Working Papers, No. 475, (2006) OECD Publishing.

5. Glaeser, E. and J. Gyourko, J.: The impact of building restrictions on housing affordability, Federal Reserve Bank of New York Economic Policy Review, June (2003).

6. Glaeser, E., J. Gyourko J., Saks, R.: Why have housing prices gone up?, Harvard Institute of Economic Research Discussion Paper, No. 2061 (2005).

7. Gyourko, J., C. Mayer, C., Sinai, T.: Superstar cities, Wharton Working Paper, July (2004).

8. Hendershott, P., Slemrod, J.: Taxes and the User Cost of Capital for Owner-Occupied Housing, AREUEA Journal, Winter, 10 (4), 375-393 (1983).

9. Himmelberg, C., Mayer, C., Sinai, T.: Assessing High House Prices: Bubbles, Fundamentals and Misperceptions, NBER Working Paper 11643 (2005).

10. McCarthy, J. and R. Peach, R.: Are home prices the next bubble?, Federal Reserve Bank of New York Economic Policy Review, Federal Reserve Bank of New York, December (2004).

11. Muth, R. F.: The Demand for Nonfarm Housing,h in A. C. Harberger, ed., The Demand for Durable Goods. Chicago: University of Chicago Press (1960).

12. Poterba, J.: Tax Subsidies to Owner-occupied Housing: An Asset Market Approach, Quarterly Journal of Economics 99, 729-52 (1984).

13. Poterba, J. : Taxation and housing: Old questions, new answers, American Economic Review, Vol. 82 (2). (1992).

14. Shiller, R. J.: Irrational Exuberance, 2nd. Edition, Princeton University Press, (2005).

15. Saxton, J.: The U.S. Housing Bubble And The Global Financial Crisis: Housing And Housing-Related, Finance, Joint Economic Committee, United States Congress, May (2008).

16. Taylor, John B. (1993), Macroeconomic Policy in a World Economy: From Econometric Design to Practical Operation, W.W. Norton, New York.

17. Taylor, J. B., Housing and Monetary Policy NBER Working Paper Series 13682 (2007). 